\title{
COPD in individuals with the PiMZ alpha-1 antitrypsin genotype
}

\author{
Haitham S. Al Ashry and Charlie Strange \\ Affiliation: Division of Pulmonary, Critical Care, Allergy and Sleep Medicine, Medical University of South \\ Carolina, Charleston, SC, USA. \\ Correspondence: Charlie Strange, Division of Pulmonary, Critical Care, Allergy and Sleep Medicine, 816 CSB, \\ MSC630, Medical University of South Carolina, Charleston, SC 29425, USA. E-mail: strangeclamusc.edu
}

@ERSpublications

MZ smokers are at increased risk for emphysema http://ow.ly/ur6f30fufZ1

Cite this article as: Al Ashry HS, Strange C. COPD in individuals with the PiMZ alpha-1 antitrypsin genotype. Eur Respir Rev 2017; 26: 170068 [https://doi.org/10.1183/16000617.0068-2017].

ABSTRACT Since the discovery of severe alpha-1 antitrypsin deficiency as a genetic risk factor for emphysema, there has been ongoing debate over whether individuals with intermediate deficiency with one protease inhibitor $\mathrm{Z}$ allele (PiMZ, or MZ) are at some risk for emphysema. This is important, because $\mathrm{MZ}$ individuals comprise $2-5 \%$ of the general population. In this review we summarise the evidence about the risks of the MZ population to develop emphysema or asthma. We discuss the different study designs that have tried to answer this question. The risk of emphysema is more pronounced in case-control than in population-based studies, perhaps due to inadequate power. Carefully designed family studies show an increased risk of emphysema in MZ smokers. This is supported by the rapid decline in lung function of $\mathrm{MZ}$ individuals when compared to the general population after massive environmental exposures. The risk of asthma in MZ subjects is less studied, and more literature is needed before firm conclusions can be made. Augmentation therapy in MZ individuals is not supported by any objective studies. MZ smokers are at increased risk for emphysema that is more pronounced when other environmental challenges are present.

\section{Introduction}

Alpha-1 antitrypsin (AAT) is a proteinase inhibitor produced by the SERPINA1 gene that protects the alveoli against the destructive effects of neutrophil elastase and other proteases [1]. In 1963, LAURELL and ERIKSSON [2] described five cases with severe AAT deficiency diagnosed using agar gel electrophoresis, three of whom developed emphysema at a young age (ranging from 30 to 42 years). A unique nomenclature is used in AAT deficiency in which the proteins are named using the prefix "Pi" (protease inhibitor), and their variants are assigned letters based on the position of the serum protein bands on acid starch gel electrophoresis, with $\mathrm{M}$ being the normal variant and $\mathrm{Z}$ the most common pathogenic one [3]. Individuals in whom both alleles make $\mathrm{Z}$ type protein (PiZZ, often abbreviated to ZZ) have severe AAT deficiency, with sera levels reaching only $10-15 \%$ of those in whom both proteins are M (PiMM, or MM) [4]. After the SERPINA1 genes on chromosome 14 were discovered, the protein nomenclature was adopted for the individual alleles and, by inference, the population affected by these genes. ZZ individuals, and especially smokers, have a faster decline in forced expiratory volume in $1 \mathrm{~s}$ (FEV1) and a shorter life expectancy than the normal population $[5,6]$. The goal here is to review the evidence concerning the risk for chronic obstructive pulmonary disease (COPD) and asthma in individuals that carry one $\mathrm{Z}$ allele and one $\mathrm{M}$ allele (MZ), who have serum AAT levels intermediate between MM and ZZ individuals (figure 1).

Received: June 122017 | Accepted after revision: July 252017

Conflict of interest: Disclosures can be found alongside this article at err.ersjournals.com

Provenance: Submitted article, peer reviewed.

Copyright CERS 2017. ERR articles are open access and distributed under the terms of the Creative Commons Attribution Non-Commercial Licence 4.0. 


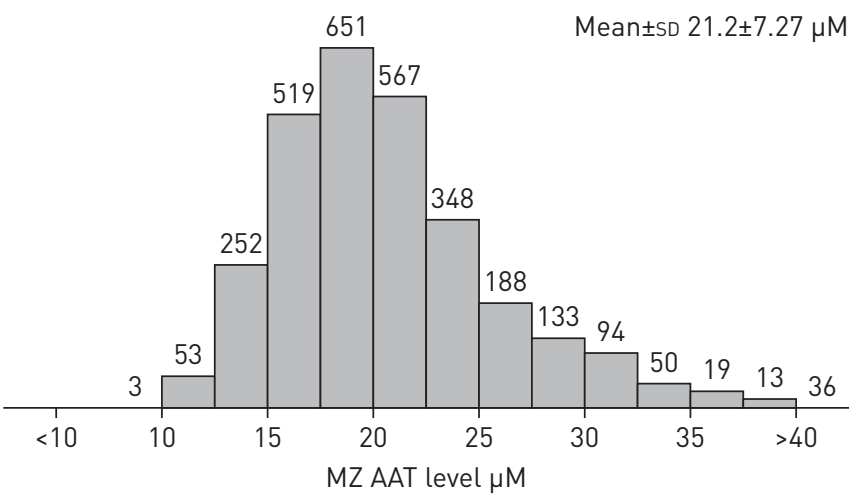

FIGURE 1 Distribution of alpha-1 antitrypsin (AAT) levels among an MZ cohort ( $n=2923$ ). Bars and numbers represent subjects with the corresponding level of AAT depicted on the x-axis. Data obtained from the Alpha-1 Coded Testing Study at the Medical University of South Carolina (Charleston, SC, USA) [7].

Currently, AAT augmentation therapy is recommended for ZZ individuals based on evidence from some observational studies that show improved survival $[8,9]$ and randomised controlled trials that show slower progression of emphysema $[10,11]$.

As the debates about the efficacy of intravenous augmentation therapy for ZZ individuals come to a close, individuals with serum levels higher than the $\mathrm{ZZ}$ population but lower than MM subjects remain more controversial. Serum AAT levels in MZ individuals are about $60 \%$ of the levels in their MM counterparts [12]. Because $M Z$ individuals constitute larger portions of the overall population than $\mathrm{ZZ}$ individuals, any testing programme that is focused on COPD cohorts will find many individuals with emphysema and MZ genotypes. The frequency of MZ individuals in the general population depends, in part, on population ethnicity, but ranges from $1.8 \%$ to $5 \%$ in most cohorts with significant European descent [13]. This is compared to an average PiZZ prevalence of $0.07-0.1 \%$ for Caucasian populations [13]. In a review of worldwide databases that have studied PIMZ prevalence, the MZ population was estimated to be at least 27 million [14]. In screening programmes, the percentage of MZ individuals varies significantly, even within the same country, from $3.6 \%$ to up to $22 \%$ (figure 2 ) $[15,16]$.

\section{Prevalence of COPD in MZ individuals}

Several studies have evaluated whether COPD is more prevalent in MZ individuals than in MM ones. Although this seems like a simple task, there are many biases that can interfere with study design. The main sources of bias include ascertainment bias and differential smoking prevalence or age as confounders. When coupled with a rare disease that does not have universal testing and the many ways that COPD has been diagnosed over the past 40 years, the data become more difficult to interpret.

Population-based cross-sectional studies

Many different study designs have been used to study the hypothesis that MZ individuals have an increased risk for COPD. The strongest data would emerge from population-based studies. Some

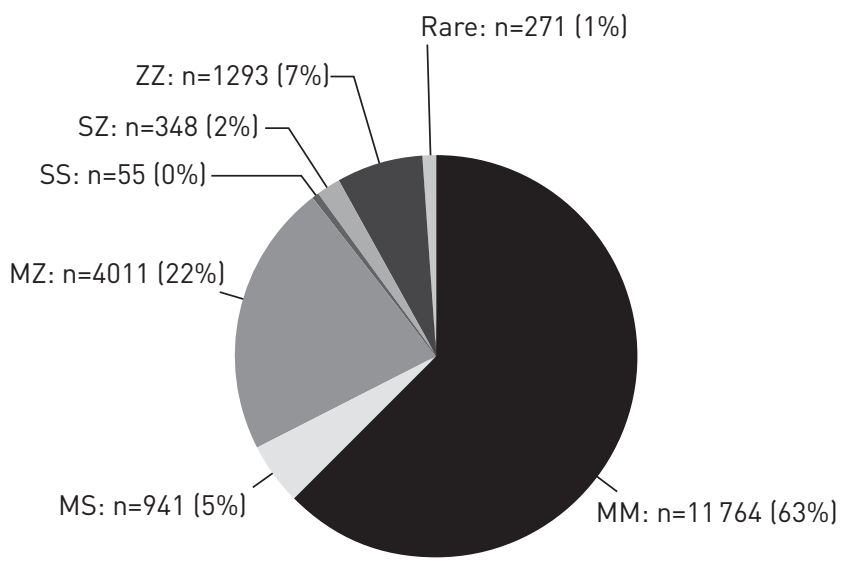

FIGURE 2 Frequency of the alpha-1 antitrypsin phenotypes in the targeted screening programme carried out by GREULiCH et al. [15] in Germany over the period 2003-2015. Reproduced and modified from [15] with permission. 
population-based cross-sectional studies show significantly lower lung function and evidence of emphysema in MZ smokers than in MM smokers [17, 18]. Other similar studies do not show any difference in spirometry in $M Z$ compared to $M M$ populations $[19,20]$. The extent to which these data are attributable to inadequate matching for COPD risk factors, such as age and smoking, remains under debate. One cross-sectional study from Tulsa, a mining centre in Bosnia, found statistically less smoking and working in mining among MZ individuals when compared to MM ones [21]. One explanation proposed was that self-awareness of respiratory symptoms leads MZ individuals in this cohort to avoid mining and smoking [21]. However, the majority of studies that have used population-based cohorts to match MZ to MM individuals failed to show any difference in spirometry [22-28]. Some of these studies included subjects aged $<50$ years in their statistical analyses [22, 25, 26, 28]. Because some ZZ individuals may not experience decline in lung function until the age of 50 years [29], it seems reasonable not to draw strong conclusions from spirometry-based studies that include young MZ individuals. HersH et al. [30] conducted a meta-analysis of 16 studies to estimate the net risk of COPD in MZ as compared to MM individuals. Five studies were population-based in design and showed an odds ratio of 1.50 (95\% CI 0.97-2.31) that MZ individuals had increased risk for COPD. In contrast, 11 case-control studies had a higher odds ratio of 2.97 (95\% CI 2.08-4.26) that MZ individuals did have an excess risk for COPD [30].

Because FEV1 and FEV1/forced vital capacity (FVC) are not sensitive measurements for individuals destined to advance to defined airway obstruction, some investigators evaluated other lung function parameters. LAM et al. [31] examined a group of $22 \mathrm{MZ}$ individuals aged $\geqslant 30$ years and found a statistically significant decrease in peak expiratory flows and an increase in pulmonary resistance in MZ subjects who smoked when compared to nonsmokers. Because smoking is a major confounder of COPD risk, some studies compared MZ nonsmokers to MM nonsmokers and found lower peak expiratory flows in the former [32, 33]. However, other studies did not show any decrease in mid-expiratory flow rates among MZ subjects [22, 34, 35]. This was also true when $M Z$ were carefully matched to $M M$, and even when smokers from each group were compared $[22,35]$. Other studies showed increased closing capacity and residual volume as well as small loss in elastic recoil in MZ individuals (including nonsmokers) compared to MM individuals [33, 36].

In some of these cross-sectional studies there was no difference in the reported respiratory symptoms suggestive of obstructive lung disease $[18,19,22,25]$. This can be explained by the fact that it takes a significant drop in lung function before respiratory symptoms ensue. In addition, some studies on the prevalence of respiratory symptoms in MZ individuals included a significant number of subjects aged $<40$ years among their samples [19, 22, 25].

\section{Case-control studies}

Many case-control studies have shown a higher prevalence of MZ subjects among patients with COPD compared to normal controls without COPD [37-44]. A significant limitation in some of these studies is the lack of adjustment for important confounders such as age and smoking [37, 39, 41-44]. Some studies matched for age and smoking and still found an increased prevalence of MZ among COPD cases, identified by spirometry and/or chest radiography [38, 40, 45]. In a cohort of smokers, SANDFORD et al. [45] found more MZ individuals in the group with COPD, identified based on FEV $1 / \mathrm{FVC}<0.7$, than the smoker control group that did not have COPD. The mean age of the two groups ranged from 59 to 64 years [45]. In the meta-analysis by Hersh et al. [30], the studies that adjusted for smoking had a less pronounced odds ratio of 1.61 (95\% CI 0.92-2.81).

The higher odds ratio in case-control studies when compared to population cross-sectional studies is not uncommon in rare genetic diseases. One critical issue is to find a large enough population-based sample to include an adequate number of individuals with the genetic and environmental risks for clinical disease. If no effort is made to ascertain that cases and controls are from the same at-risk population, genetic differences may exist and there may be genes other than MZ responsible for the obstructive lung disease in the COPD arms in case-control studies.

Subsequent to the meta-analysis of HeRsh et al. [30], a case-control study including 1669 subjects from Norway was published by SøRHEIM et al. [46]. Global Initiative for Chronic Obstructive Lung Disease (GOLD) spirometric stage II COPD subjects ( $\mathrm{n}=834 ; 790 \mathrm{MM}$ and $44 \mathrm{MZ}$ ) and controls with normal spirometry ( $\mathrm{n}=835 ; 801 \mathrm{MM}$ and $34 \mathrm{MZ}$ ) were Caucasians aged $\geqslant 40$ years with current or ex-smoking of $\geqslant 2.5$ pack-years. Standardised high-resolution computed tomography (CT) scans of the chest were obtained in $50 \%$ of the subjects. Quantitative assessment of low attenuation areas showed more disease in MZ individuals, a mean 3.5\% lower FEV1/FVC, but no difference in the age, sex, height and pack-years of smoking adjusted COPD risk by genotype [46].

In summary, the data from case-control studies find more emphysema and lower lung function in MZ than in MM populations when appropriately adjusted for age and smoking covariates. The strength of 
these studies is moderate, and better when emphysema is quantified independently of spirometric variables. Because CT emphysema is correlated to mortality in AAT deficiency while lung function is not [47], these studies are sufficient to demonstrate an increased risk for COPD in MZ subjects.

\section{Family-based studies}

Family-based studies attempt to compare siblings who have different genes at the SERPINA1 locus to determine if the COPD risk is different. The advantage to these studies is that childhood environmental exposures and some other genetic variations are shared in these populations. In a study conducted by KUEPPERs et al. [48], 114 siblings of COPD patients were compared to 114 siblings of healthy controls and found no difference in $\mathrm{MZ}$ prevalence. Of note, the percentage of $\mathrm{MZ}$ in controls was higher than is usually reported in such populations, which raises a concern about selection bias. In fact, the authors found a higher percentage of MZ subjects in siblings of index cases when compared to normal blood donors from the same institution $(7.9 \%$ versus $2.4 \% ; \mathrm{p}<0.02)$ [48]. In some family studies, MZ subjects had abnormal ventilation-perfusion scans in the lower lobes, even among MZ children [49, 50]. SøRHEIM et al. [46] conducted a multicentre family-based study in Europe and North America and included 2707 subjects. COPD probands had a smoking history of $\geqslant 5$ pack-years and had at least one sibling who had smoked for $\geqslant 5$ pack-years. They were also required to have a FEV1 of $<60 \%$ predicted and a FEV1/vital capacity (VC) ratio of $<90 \%$ predicted. Most of the included relatives were siblings of their respective probands. Chest CT, spirometry and respiratory questionnaires were obtained in all subjects $[46,51]$. The COPD proband group had 984 subjects (941 MM and $43 \mathrm{MZ}$ ) and the relatives group included 1723 subjects (1651 MM and $72 \mathrm{MZ}$ ). After adjusting for covariates, MZ individuals had more emphysema on $\mathrm{CT}$ scan and a 3.9\% lower $\mathrm{FEV} 1 / \mathrm{VC}$ ratio than MM individuals [46]. In another family study MolLoY et al. [52] demonstrated that MZ subjects are at increased risk for COPD only if they smoke. This study adjusted for sex, age and years of smoking. Most importantly, in this study, the MZ COPD probands were excluded from analysis. In family-based genetic studies, selection bias can influence results. Because this study included a homogeneously ethnic group, adjusted for important covariates, and avoided sampling bias, it provides strong and clear evidence that ever-smoker MZ individuals are at higher risk for COPD than MM counterparts [52].

\section{Complications of our understanding by common biases in genetic studies}

In addition to the usual biases encountered in general epidemiological studies, distinctive biases exist when studying genetic epidemiology. For instance, genotyping errors have been reported to range from $0.5 \%$ to $30 \%$ in some studies [53]. Genotyping errors have been reported during the diagnosis of AAT deficiency $[54,55]$.

Because SERPINA1 is known to be associated with COPD, this gene has been purposefully removed from some genetic association analyses by excluding known AAT-deficient patients [56]. However, when this was not done, the MZ genotype was seen to be associated with COPD and COPD progression in some open-ended genome-wide association studies when SERPINA1 was included as one of the loci studied [57]. In summary, case-control studies, family studies and genome-wide association studies all suggest that MZ individuals are more susceptible to COPD than those with MM genotypes, particularly if cigarette smoking is present during ageing.

\section{Progression of obstructive lung disease in $\mathrm{MZ}$ individuals}

Whether lung function and respiratory symptoms worsen more over time in MZ than in MM individuals has been studied in a few cohorts (table 1). Some of these longitudinal studies are limited by short interval follow-up (2-3 years), and this may explain their negative results [58,59]. In a 6-year longitudinal study, MADison et al. [60] found 20-40 mL more yearly FEV1 decline in MZ than in MM individuals, regardless of smoking status. In a prospective cohort that followed iron-ore miners for 5 years, $\mathrm{MZ}$ individuals had more decline in FEV1/FVC than MM ones, but there was no difference in respiratory symptoms [61]. In another 10-year longitudinal study among a cohort of nonsmokers matched for age, height and body weight, pulmonary elasticity was measured and was found to decrease significantly over time in the MZ group when compared to the MM group [62]. In smokers there was a significant difference in FEV1, with annual decline of $75 \mathrm{~mL}$ in $\mathrm{MZ}$ versus $53 \mathrm{~mL}$ in MM subjects [63]. In an 11-year prospective cohort, the annual decline in forced expiratory flow at 25-75\% of FVC (FEF25-75\%) among persistent smokers was $108.2 \mathrm{~mL} \cdot \mathrm{s}^{-1} \cdot$ year $^{-1}$ versus $66.8 \mathrm{~mL} \cdot \mathrm{s}^{-1} \cdot \mathrm{year}^{-1}$ in $\mathrm{MZ}$ and MM subjects, respectively [64].

SiLVA et al. [58] followed a randomly selected population from Arizona (USA) for an average of 15 years and found no difference in the annual decline of lung function in $58 \mathrm{MZ}$ and $1802 \mathrm{MM}$ individuals in this potentially underpowered study [65]. The longest longitudinal study was the population-based prospective cohort study conducted by DAHL et al. [66]. They randomly selected 9187 adults from the Danish general population and followed them over 21 years. One of the strengths of the study is that the frequency of 
TABLE 1 Studies that compare the decline of lung function over time between $M M$ and $M Z$ individuals

\begin{tabular}{|c|c|c|c|c|c|}
\hline First author [ref.] & Year & $\begin{array}{c}\text { Average } \\
\text { follow-up } \\
\text { duration years }\end{array}$ & Population & $\begin{array}{l}\text { Adjustment for } \\
\text { confounders }\end{array}$ & $\begin{array}{l}\text { Faster decline in lung } \\
\text { function in MZ compared } \\
\text { to MM individuals? }\end{array}$ \\
\hline MADISON [60] & 1981 & 6 & $\begin{array}{c}82 \mathrm{MM} \text { compared to } 42 \mathrm{MZ} \\
\text { individuals }\end{array}$ & Yes & Only in MZ men \\
\hline PierRe [61] & 1988 & 5 & $\begin{array}{l}757 \mathrm{MM} \text { compared to } 21 \mathrm{MZ} \\
\text { iron-ore miners }\end{array}$ & $\begin{array}{l}\text { No difference in age, } \\
\text { length of employment, or } \\
\text { smoking }\end{array}$ & Yes \\
\hline TARJÁN [62] & 1994 & 10 & $\begin{array}{c}28 \text { nonsmoking matched } \mathrm{MM} \text { and } \\
\text { MZ pairs }\end{array}$ & Yes & Yes \\
\hline SANDFORD [57] & 2001 & 5 & $\begin{array}{l}283 \text { subjects with rapid decline } \\
\text { compared to } 308 \text { subjects with no } \\
\text { decline in lung function }\end{array}$ & Yes & $\begin{array}{l}\text { More MZ individuals were } \\
\text { found in the rapid decline } \\
\text { group }\end{array}$ \\
\hline SILVA [58] & 2003 & 15 & $\begin{array}{c}1802 \mathrm{MM} \text { compared to } 58 \mathrm{MZ} \\
\text { individuals selected randomly from } \\
\text { an Arizona population }\end{array}$ & Yes & No \\
\hline Thun [64] & 2012 & 11 & $\begin{array}{l}4207 \mathrm{MM} \text { compared to } 112 \mathrm{MZ} \\
\text { individuals }\end{array}$ & Yes & $\begin{array}{l}\text { Only in FEF } 25-75 \% \text { among } \\
\text { persistent smokers }\end{array}$ \\
\hline
\end{tabular}

FEF25-75\%: forced expiratory flow at $25-75 \%$ of forced vital capacity.

alleles did not differ significantly from that predicted by Hardy-Weinberg equilibrium [66]. The MZ genotype was found in 451 participants. After adjusting for age, sex, tobacco consumption and FEV1 at study entry, MZ individuals had 50\% more incidence of COPD, as well as $50 \%$ more chance of hospitalisation and death from COPD, when compared to MM subjects. Although there was a statistical difference in the annual decline of FEV1 in MZ compared to MM individuals, the mean difference was only $4 \mathrm{~mL}$, with mean \pm SD annual decline of $25 \pm 1.9 \mathrm{~mL}$ in $\mathrm{MZ}$ versus $21 \pm 0.5 \mathrm{~mL}$ in the MM population. Interestingly, when grouped based on smoking status, the decline in FEV1 was similar among MZ and MM smokers. When nonsmokers were compared, the difference in annual decline in FEV1 was worse by $7 \mathrm{~mL}$ every year in $\mathrm{MZ}(20 \pm 2.9 \mathrm{~mL})$ compared to MM individuals $(13 \pm 0.7 \mathrm{~mL})$ [66]. SANDFORD et al. [57] found a threefold increased frequency of MZ individuals among smokers with rapid decline in FEV1 $\left(-154 \pm 3 \mathrm{~mL} \cdot \mathrm{year}^{-1}\right)$ versus smokers that did not have rapid decline $\left(+15 \pm 2 \mathrm{~mL} \cdot \mathrm{year}^{-1}\right)$. The association of $\mathrm{MZ}$ with rapid decline in lung function among smokers was more pronounced, with an odds ratio of 9.7, among currently smoking MZ individuals who had a family history of COPD [57].

\section{Effects of environmental and occupational exposures}

Environmental and occupational exposures are linked to the development of COPD in the general population [67-70]. In homozygous ZZ individuals, exposure to dust, gas and fumes leads to a greater decline in lung function, even in nonsmoking ZZ subjects, particularly after the age of 50 years $[71,72]$. In children exposed to passive smoking, MZ individuals had a greater decline in lung function than MM children [73, 74]. To account for environmental exposures, some population-based cross-sectional studies compared MZ to MM groups among industry workers [18, 61, 75]. Some of the studies that found an increased frequency of MZ genotypes in industry workers with COPD lacked matching for age and smoking [61, 76]. Horne et al. [18] compared MZ and MM grain workers and matched for age, years of employment and smoking. FEV1 and FEV1/FVC were worse in the MZ group, but there was no difference in respiratory symptoms [18]. In another group of saw mill and grain workers there was no difference in respiratory symptoms or spirometry between $\mathrm{MM}$ and $\mathrm{MZ}$ subjects. However, their mean age was $<40$ years and there was no adjustment for smoking [75]. A group of MZ and MM individuals who worked in the New York City Fire Department rescue workforce during the World Trade Center collapse on September 11, 2001, were followed for 4 years. The average age was 46 years and 40 years in MZ and MM individuals, respectively. After September 11, the MZ subjects exhibited a $110 \mathrm{~mL}$ annual decline in 
FEV1, compared to 25-50 mL in their MM counterparts [77]. Meнta et al. [78] also found that exposure to dust, vapour, gas and fumes was associated with a greater decline in lung function among $97 \mathrm{MZ}$ when compared to $3546 \mathrm{MM}$ individuals with the same level of exposure. In the same study, MZ subjects exposed to small particulate matter $(\leqslant 10 \mu \mathrm{m})$ also trended towards more decline in lung function compared to their MM counterparts with the same level of exposure [78]. Cumulatively, the data suggest that MZ individuals may lose lung function faster than the MM population when exposed to air and industrial pollution.

\section{MZ level heterogeneity and impact of the acute phase response}

During the acute phase response, AAT serum concentrations increase above the normal range [79]. In states of infection or inflammation, neutrophils are recruited into the lungs and the plasma concentration of AAT increases $[80,81]$. The imbalance between neutrophil elastase and AAT is implicated in the pathogenesis of emphysema as well as other pulmonary diseases [82]. Consequently, MZ individuals may be more vulnerable to lung damage during acute inflammatory states if they are not able to raise their AAT sera levels high enough to cope with the surge of neutrophil elastase (figure 3). In asymptomatic nonsmoker MZ individuals, sputum showed levels of neutrophils and interleukin-8 similar to patients with COPD and higher than healthy controls [83]. Thun et al. [64] found that MZ individuals had more $\mathrm{COPD}$, defined as $\mathrm{FEV} 1 / \mathrm{FVC}<0.7$, than $\mathrm{MM}$ subjects with similar levels of C-reactive protein. AAT levels are very variable in MZ individuals, so serial AAT testing is not clinically recommended, because the impact of the acute phase response on AAT level is still an imprecise science. Hence, in this population, assessment of COPD risk is a complex process influenced by interactions between different factors (figure 4).

\section{Risk of asthma in the MZ population}

The risk of asthma in the MZ population has not been studied as extensively as the risk for COPD. Neutrophil elastase plays an important role in the development of airway inflammation and hyperresponsiveness, which are key factors in the pathophysiology of asthma [84]. Compared to healthy controls, patients with bronchial asthma have a higher activity of neutrophil elastase [85, 86]. In asthmatics, VIgnola et al. [87] showed that neutrophil elastase activity is negatively correlated with FEV1. Therefore, clinical epidemiology is needed to support these biochemical observations.

In the National Heart, Lung and Blood Institute Registry of AAT Deficiency, a physician diagnosis of asthma was reported in $35 \%$ of $\mathrm{ZZ}$ individuals. Wheezing without associated upper respiratory tract infections was reported in $20 \%$ of $\mathrm{ZZ}$ individuals who had FEV1 $\geqslant 80 \%$ and in $70 \%$ of those with $\mathrm{FEV}_{1}$

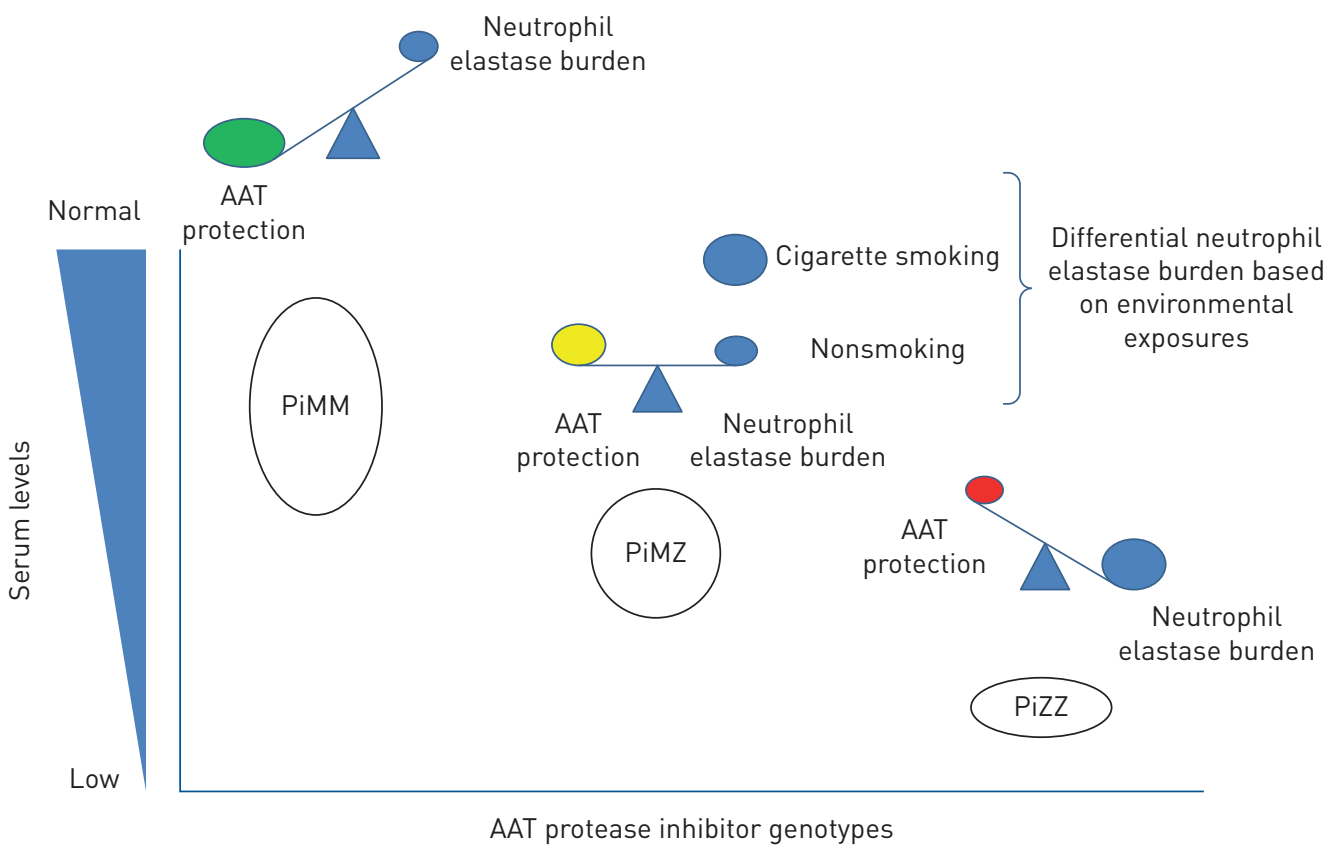

FIGURE 3 Conceptual model of the balance between alpha-1 antitrypsin (AAT) and neutrophil elastase, by genotype. 


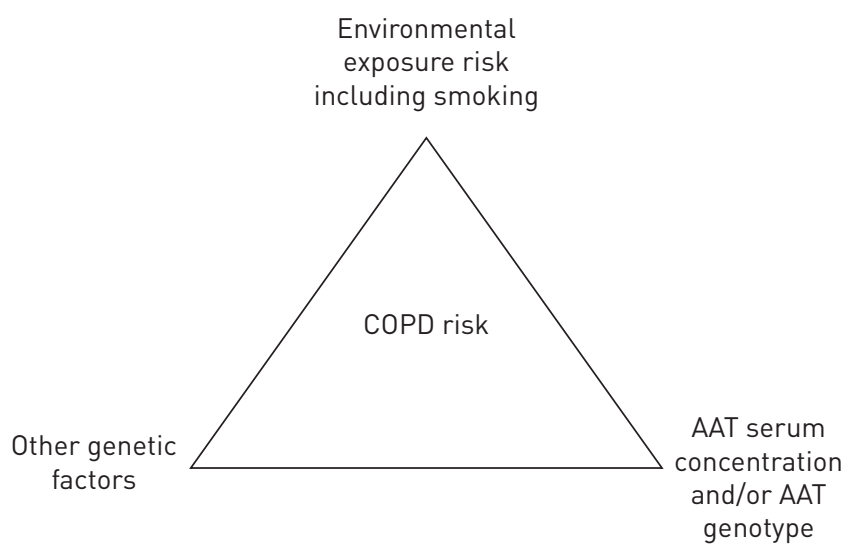

FIGURE 4 Conceptual framework of the interaction between environmental exposure including smoking, alpha-1 antitrypsin (AAT) level and/or AAT genotype, other genetic factors and chronic obstructive pulmonary disease (COPD) risk. Note that there are no studies that show that genotype is more important than blood concentration of AAT for COPD risk assessment.

$<80 \%$ [88]. When compared to non-AAT-deficient COPD patients, ZZ individuals have more reversible airway obstruction, wheezing and atopy [89].

Although the AAT/neutrophil elastase imbalance is less in MZ than in ZZ individuals, MZ individuals have more asthma, nasal polyposis, family history of atopy, and peripheral eosinophilia than the general population [90]. In another study, a physician diagnosis of asthma was reported in up to one-third of MZ subjects [91]. By contrast, a study by WenCKER et al. [16] found only 2.9\% MZ individuals among asthmatics referred for treatment of respiratory diseases in seven physicians' offices. In a subsequent study, only one MZ individual was found in a cohort of 122 patients with severe asthma [92]. In our opinion, although some evidence suggests an increased asthma risk, more studies are needed, particularly in paediatric populations.

\section{Should we ever, sometimes or never treat the MZ population?}

Historically, AAT serum levels of $11 \mu \mathrm{M}$ were considered protective against emphysema [4, 9]. This was based on a variety of assumptions that included suggestions that MZ individuals are not at increased risk of emphysema $[4,93]$. Clinical data regarding whether an individual COPD patient has emphysema from environmental factors such as cigarette smoking or from the low AAT level associated with the MZ carrier state, or both, are impossible to assemble. Therefore, the majority of the pulmonary community has awaited trials showing improved outcome with augmentation in an MZ study before prescribing this expensive therapy. A minority opinion suggests that emphysema that is out of proportion to age and smoking is sufficient reason to begin augmentation.

Some studies are in progress that may have an impact on these recommendations. So far, studies of AAT augmentation therapy in $\mathrm{ZZ}$ individuals have used a weekly, intravenous (i.v.) $60 \mathrm{mg} \cdot \mathrm{kg}^{-1}$ dose to maintain serum levels above an $11 \mu \mathrm{M}$ threshold [8, 94-97]. GADEK et al. [93] studied the bronchoalveolar lavage (BAL) AAT levels in five ZZ individuals, which improved from $15 \%$ predicted pre-infusion to 60 $70 \%$ predicted as compared to BAL AAT levels in MM individuals after 2-4 weeks of infusion therapy.

Because epithelial lining fluid anti-elastase capacity is not returned to normal with this dose, ongoing studies are evaluating the effect of $120 \mathrm{mg} \cdot \mathrm{kg}^{-1}$ weekly doses to establish whether CT density decline over 3 years is less on the high dose compared to the usual dose $\left(60 \mathrm{mg} \cdot \mathrm{kg}^{-1}\right)$ of AAT. The SPARTA (Study of ProlAstin-c Randomized Therapy with Alpha-1) augmentation trial is currently comparing the $120 \mathrm{mg} \cdot \mathrm{kg}^{-1}$ i.v. dose that produces a mean trough serum level of $27.7 \mu \mathrm{M}$ to $60 \mathrm{mg} \cdot \mathrm{kg}^{-1}$ i.v. doses weekly that produce trough levels of $17.3 \mu \mathrm{M}[98,99]$. Because the AAT level in serum and in BAL of MZ individuals averages at $20 \mu \mathrm{M}$, a positive trial will prompt a re-evaluation of the evidence by which most MZ subjects remain untreated. Designing such studies should take into consideration experience from the last 40 years of augmentation studies in ZZ subjects, particularly regarding study power [100]. Although it will be easier to recruit $\mathrm{MZ}$ individuals than $\mathrm{ZZ}$ participants because they are less rare, the rate of decline in lung function or CT densitometry may be slower. Therefore, longer follow-up periods or larger numbers of participants would be needed. Such studies should also be powered to detect differences in exacerbation rate and measure other important clinical outcomes that target the patient experience. 


\section{Conclusions}

Data suggest that MZ subjects have an increased risk of emphysema that is clinically manifest most commonly in those who have smoked cigarettes. Although the risk of emphysema is higher, there are no data that support augmentation therapy in MZ individuals [101]. Much more research needs to be done to better understand the pulmonary disease burden within the MZ community, a group of individuals that make up $2-5 \%$ of world populations with significant European descent.

\section{References}

Gettins PG. Serpin structure, mechanism, and function. Chem Rev 2002; 102: 4751-4804.

Laurell CB, Eriksson S. The electrophoretic $\alpha_{1}$-globulin pattern of serum in $\alpha_{1}$-antitrypsin deficiency. 1963. COPD 2013; 10: Suppl. 1, 3-8.

3 Cox DW, Johnson AM, Fagerhol MK. Report of nomenclature meeting for alpha 1-antitrypsin, INSERM, Rouen/ Bois-Guillaume-1978. Hum Genet 1980; 53: 429-433.

4 Crystal RG. Alpha 1-antitrypsin deficiency, emphysema, and liver disease. Genetic basis and strategies for therapy. J Clin Invest 1990; 85: 1343-1352.

5 Larsson C. Natural history and life expectancy in severe alphal-antitrypsin deficiency, Pi Z. Acta Med Scand 1978; 204: 345-351.

6 Brantly ML, Paul LD, Miller BH, et al. Clinical features and history of the destructive lung disease associated with alpha-1-antitrypsin deficiency of adults with pulmonary symptoms. Am Rev Respir Dis 1988; 138: 327-336.

7 Strange C, Monk R, Schwarz L, et al. The United States Alpha-1 Foundation Research Registry: genesis, impact and future. COPD 2015; 12: Suppl. 1, 42-45.

8 Survival and FEV1 decline in individuals with severe deficiency of alpha1-antitrypsin. The Alpha-1-Antitrypsin Deficiency Registry Study Group. Am J Respir Crit Care Med 1998; 158: 49-59.

9 American Thoracic Society, European Respiratory Society. American Thoracic Society/European Respiratory Society statement: standards for the diagnosis and management of individuals with alpha-1 antitrypsin deficiency. Am J Respir Crit Care Med 2003; 168: 818-900.

10 Chapman KR, Burdon JG, Piitulainen E, et al. Intravenous augmentation treatment and lung density in severe $\alpha_{1}$ antitrypsin deficiency (RAPID): a randomised, double-blind, placebo-controlled trial. Lancet 2015; 386: 360-368.

11 McElvaney NG, Burdon J, Holmes M, et al. Long-term efficacy and safety of $\alpha_{1}$ proteinase inhibitor treatment for emphysema caused by severe $\alpha_{1}$ antitrypsin deficiency: an open-label extension trial (RAPID-OLE). Lancet Respir Med 2017; 5: 51-60.

12 Ferrarotti I, Thun GA, Zorzetto $M$, et al. Serum levels and genotype distribution of $\alpha_{1}$-antitrypsin in the general population. Thorax 2012; 67: 669-674.

13 Janus ED, Joyce PR, Sheat JM, et al. Alpha-1-antitrypsin variants in New Zealand. NZ Med J 1975; 82: 289-291.

14 de Serres FJ. Worldwide racial and ethnic distribution of alpha1-antitrypsin deficiency: summary of an analysis of published genetic epidemiologic surveys. Chest 2002; 122: 1818-1829.

15 Greulich T, Nell C, Herr C, et al. Results from a large targeted screening program for alpha-1-antitrypsin deficiency: 2003-2015. Orphanet J Rare Dis 2016; 11: 75.

16 Wencker M, Marx A, Konietzko N, et al. Screening for $\alpha_{1}$-Pi deficiency in patients with lung diseases. Eur Respir J 2002; 20: 319-324.

17 Klayton R, Fallat R, Cohen AB. Determinants of chronic obstructive pulmonary disease in patients with intermediate levels of $\alpha_{1}$-antitrypsin. Am Rev Respir Dis 1975; 112: 71-75.

18 Horne SL, Tennent RK, Cockcroft DW, et al. Pulmonary function in Pi M and MZ grainworkers. Chest 1986; 89: 795-799.

19 Webb DR, Hyde RW, Schwartz RH, et al. Serum $\alpha_{1}$-antitrypsin variants. Prevalence and clinical spirometry. Am Rev Respir Dis 1973; 108: 918-925.

20 Gulsvik, A, Fagerhol MK. Alpha 1-antitrypsin phenotypes and obstructive lung disease in the city of Oslo. Scand J Respir Dis 1979; 60: 267-274.

21 Webb DR, Hyde RW, Schwartz RH, et al. Intermediate $\alpha_{1}$-antitrypsin deficiency and chronic obstructive pulmonary disease in Yugoslavia. Am Rev Respir Dis 1978; 117: 1039-1043.

22 Morse JO, Lebowitz MD, Knudson RJ, et al. Relation of protease inhibitor phenotypes to obstructive lung diseases in a community. N Engl J Med 1977; 296: 1190-1194.

23 Groth S, Lindell SE, Kabiraj MU, et al. Bronchial reactivity and small airway dysfunction in subjects with intermediate $\alpha_{1}$-antitrypsin deficiency. Bull Eur Physiopathol Respir 1984; 20: 279-284.

24 Kabiraj MU, Simonsson BG, Groth S, et al. Bronchial reactivity, smoking, and $\alpha_{1}$-antitrypsin. A population-based study of middle-aged men. Am Rev Respir Dis 1982; 126: 864-869.

25 Buist AS, Sexton GJ, Azzam AM, et al. Pulmonary function in heterozygotes for $\alpha_{1}$-antitrypsin deficiency: a case-control study. Am Rev Respir Dis 1979; 120: 759-766.

26 Christensson P, Arborelius M Jr, Kautto-Wiberg R. Changes of volume of trapped gas after bronchodilation in subjects with suspected subclinical emphysema. Respiration 1986; 49: 16-22.

27 Gerblich AA, Kleinerman J, Rynbrandt DJ, et al. Pi-Z phenotypes in a pulmonary clinic. Their prevalence and physiologic state. Am J Clin Pathol 1978; 69: 509-513.

28 Bruce RM, Cohen BH, Diamond EL, et al. Collaborative study to assess risk of lung disease in Pi MZ phenotype subjects. Am Rev Respir Dis 1984; 130: 386-390.

29 Tanash HA, Nilsson PM, Nilsson JA. Clinical course and prognosis of never-smokers with severe alpha-1-antitrypsin deficiency (PiZZ). Thorax 2008; 63: 1091-1095.

30 Hersh CP, Dahl M, Ly NP, et al. Chronic obstructive pulmonary disease in $\alpha_{1}$-antitrypsin PI MZ heterozygotes: a meta-analysis. Thorax 2004; 59: 843-849.

31 Lam S, Abboud RT, Chan-Yeung M, et al. Neutrophil elastase and pulmonary function in subjects with intermediate $\alpha_{1}$-antitrypsin deficiency (MZ phenotype). Am Rev Respir Dis 1979; 119: 941-951.

32 Cooper DM, Hoeppner V, Cox D, et al. Lung function in $\alpha_{1}$-antitrypsin heterozygotes (Pi type MZ). Am Rev Respir Dis 1974; 110: 708-715. 
Hall WJ, Hyde RW, Schwartz RH, et al. Pulmonary abnormalities in intermediate alpha-1-antitrypsin deficiency. J Clin Invest 1976; 58: 1069-1077.

Gelb AF, Klein E, Lieberman J. Pulmonary function in nonsmoking subjects with alpha ${ }_{1}$ antitrypsin deficiency (MZ phenotype). Am J Med 1977; 62: 93-98.

Lebowitz MD, Knudson RJ, Morse JO, et al. Closing volume and flow volume abnormalities in alpha -antitrypsin $_{1}$ phenotype groups in a community population. Am Rev Respir Dis 1978; 117: 179-181.

Larsson C, Eriksson S, Dirksen H. Smoking and intermediate $\alpha_{1}$-antitrypsin deficiency and lung function in middle-aged men. Br Med J 1977; 2: 922-925.

Barnett TB, Gottovi D, Johnson AM. Protease inhibitors in chronic obstructive pulmonary disease. Am Rev Respir Dis 1975; 111: 587-593.

Bartmann K, Fooke-Achterrath M, Koch G, et al. Heterozygosity in the Pi-system as a pathogenetic cofactor in chronic obstructive pulmonary disease (COPD). Eur J Respir Dis 1985; 66: 284-296.

Matzen RN, Bader PI, Block WD. alpha1-Antitrypsin deficiency in clinic patients. Ann Clin Res 1977; 9: 88-92. Shigeoka JW, Hall WJ, Hyde RW, et al. The prevalence of alpha-antitrypsin heterozygotes (Pi MZ) in patients with obstructive pulmonary disease. Am Rev Respir Dis 1976; 114: 1077-1084.

Cox DW, Hoeppner VH, Levison H. Protease inhibitors in patients with chronic obstructive pulmonary disease: the alpha-antitrypsin heterozygote controversy. Am Rev Respir Dis 1976; 113: 601-606.

Kueppers F, Dönhardt A. Obstructive lung disease in heterozygotes for alpha-1 antitrypsin deficiency. Ann Intern Med 1974; 80: 209-212.

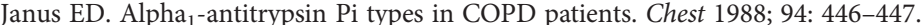

Lieberman J, Winter B, Sastre A. Alpha ${ }_{1}$-antitrypsin Pi-types in 965 COPD patients. Chest 1986; 89: 370-373.

Sandford AJ, Weir TD, Spinelli JJ, et al. Z and S mutations of the $\alpha_{1}$-antitrypsin gene and the risk of chronic obstructive pulmonary disease. Am J Respir Cell Mol Biol 1999; 20: 287-291.

Sørheim IC, Bakke P, Gulsvik A, et al. $\alpha_{1}$-Antitrypsin protease inhibitor MZ heterozygosity is associated with airflow obstruction in two large cohorts. Chest 2010; 138: 1125-1132.

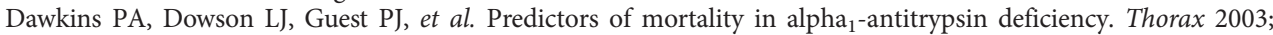
58: $1020-1026$

Kueppers F, Miller RD, Gordon $\mathrm{H}$, et al. Familial prevalence of chronic obstructive pulmonary disease in a matched pair study. Am J Med 1977; 63: 336-342.

Johnson TF, Reisman RE, Arbesman CE, et al. Obstructive airway disease associated with heterozygous alpha-1-antitrypsin deficiency. J Allergy Clin Immunol 1976; 58: 69-75.

Benjamin JJ, Cohen BH, Ball WC Jr, et al. Chronic obstructive pulmonary disease and alpha-1-antitrypsin (Pi) variation: a family study. Birth Defects Orig Artic Ser 1974; 10: 212-216.

Patel BD, Coxson HO, Pillai SG, et al. Airway wall thickening and emphysema show independent familial aggregation in chronic obstructive pulmonary disease. Am J Respir Crit Care Med 2008; 178: 500-505.

Molloy K, Hersh CP, Morris VB, et al. Clarification of the risk of chronic obstructive pulmonary disease in $\alpha_{1}$-antitrypsin deficiency PiMZ heterozygotes. Am J Respir Crit Care Med 2014; 189: 419-427.

Little J, Higgins JP, Ioannidis JP, et al. STrengthening the REporting of Genetic Association Studies (STREGA): an extension of the STROBE statement. PLoS Med 2009; 6: e22.

Greene DN, Procter M, Grenache DG, et al. Misclassification of an apparent alpha 1-antitrypsin "Z" deficiency variant by melting analysis. Clin Chim Acta 2011; 412: 1454-1456.

McElvaney NG. Diagnosing $\alpha_{1}$-antitrypsin deficiency: how to improve the current algorithm. Eur Respir Rev 2015; 24: 52-57.

Repapi E, Sayers I, Wain LV, et al. Genome-wide association study identifies five loci associated with lung function. Nat Genet 2010; 42: 36-44.

Sandford AJ, Chagani T, Weir TD, et al. Susceptibility genes for rapid decline of lung function in the lung health study. Am J Respir Crit Care Med 2001; 163: 469-473.

Silva GE, Sherrill DL, Guerra S, et al. A longitudinal study of $\alpha_{1}$-antitrypsin phenotypes and decline in FEV1 in a community population. Chest 2003; 123: 1435-1440.

de Hamel FA, Carrell RW. Heterozygous alpha 1-antitrypsin deficiency: a longitudinal lung function study. NZ Med J 1981; 94: 407-410.

Madison R, Mittman C, Afifi AA, et al. Risk factors for obstructive lung disease. Am Rev Respir Dis 1981; 124: 149-153.

Pierre F, Pham QT, Mur JM, et al. Respiratory symptoms and pulmonary function in 871 miners according to $\mathrm{Pi}$ phenotype: a longitudinal study. Eur J Epidemiol 1988; 4: 39-44.

Tarján E, Magyar P, Váczi Z, et al. Longitudinal lung function study in heterozygous PiMZ phenotype subjects. Eur Respir J 1994; 7: 2199-2204.

Eriksson S, Lindell SE, Wiberg R. Effects of smoking and intermediate $\alpha_{1}$-antitrypsin deficiency (PiMZ) on lung function. Eur J Respir Dis 1985; 67: 279-285.

Thun GA, Ferrarotti I, Imboden M, et al. SERPINA1 PiZ and PiS heterozygotes and lung function decline in the SAPALDIA cohort. PLoS One 2012; 7: e42728.

Seersholm N. Pi MZ and COPD: will we ever know? Thorax 2004; 59: 823-825. pulmonary disease in $\alpha_{1}$-antitrypsin MZ heterozygotes: a longitudinal study of the general population. Ann Intern Med 2002; 136: 270-279.

Ko FW, Hui DS. Air pollution and chronic obstructive pulmonary disease. Respirology 2012; 17: 395-401.

Boschetto P, Quintavalle S, Miotto D, et al. Chronic obstructive pulmonary disease (COPD) and occupational exposures. J Occup Med Toxicol 2006; 1: 11.

Schikowski T, Sugiri D, Ranft U, et al. Long-term air pollution exposure and living close to busy roads are associated with COPD in women. Respir Res 2005; 6: 152.

Rice MB, Ljungman PL, Wilker EH, et al. Long-term exposure to traffic emissions and fine particulate matter and lung function decline in the Framingham Heart Study. Am J Respir Crit Care Med 2015; 191: 656-664.

Piitulainen E, Tornling G, Eriksson S. Effect of age and occupational exposure to airway irritants on lung function in non-smoking individuals with alpha 1-antitrypsin deficiency (PiZZ). Thorax 1997; 52: 244-248. 
Mayer AS, Stoller JK, Bucher Bartelson B, et al. Occupational exposure risks in individuals with $\mathrm{PI}^{\star} \mathrm{Z}$ $\alpha_{1}$-antitrypsin deficiency. Am J Respir Crit Care Med 2000; 162: 553-558.

Corbo GM, Forastiere F, Agabiti N, et al. Passive smoking and lung function in $\alpha_{1}$-antitrypsin heterozygote schoolchildren. Thorax 2003; 58: 237-241.

von Ehrenstein OS, von Mutius E, Maier E, et al. Lung function of school children with low levels of $\alpha_{1}$-antitrypsin and tobacco smoke exposure. Eur Respir J 2002; 19: 1099-1106.

Chan-Yeung M, Ashley MJ, Corey P, et al. Pi phenotypes and the prevalence of chest symptoms and lung function abnormalities in workers employed in dusty industries. Am Rev Respir Dis 1978; 117: 239-245.

Beckman G, Beckman L, Mikaelsson B, et al. Alpha-1-antitrypsin types and chronic obstructive lung disease in an industrial community in Northern Sweden. Hum Hered 1980; 30: 299-306.

Banauch GI, Brantly M, Izbicki G, et al. Accelerated spirometric decline in New York City firefighters with $\alpha_{1}$-antitrypsin deficiency. Chest 2010; 138: 1116-1124.

Mehta AJ, Thun GA, Imboden M, et al. Interactions between SERPINA1 PiMZ genotype, occupational exposure and lung function decline. Occup Environ Med 2014; 71: 234-240.

Gilutz H, Siegel Y, Paran E, et al. Alpha 1-antitrypsin in acute myocardial infarction. Br Heart J 1983; 49: 26-29. Sandhaus RA, Turino G. Neutrophil elastase-mediated lung disease. COPD 2013; 10: Suppl. 1, 60-63.

Stolk J, Seersholm N, Kalsheker N. Alpha ${ }_{1}$-antitrypsin deficiency: current perspective on research, diagnosis, and management. Int J Chron Obstruct Pulmon Dis 2006; 1: 151-160.

103-106.

Malerba M, Ricciardolo F, Radaeli A, et al. Neutrophilic inflammation and IL-8 levels in induced sputum of alpha-1-antitrypsin PiMZ subjects. Thorax 2006; 61: 129-133.

Koga H, Miyahara N, Fuchimoto Y, et al. Inhibition of neutrophil elastase attenuates airway hyperresponsiveness and inflammation in a mouse model of secondary allergen challenge: neutrophil elastase inhibition attenuates allergic airway responses. Respir Res 2013; 14: 8.

Simpson JL, Scott RJ, Boyle MJ, et al. Differential proteolytic enzyme activity in eosinophilic and neutrophilic asthma. Am J Respir Crit Care Med 2005; 172: 559-565.

Katainen E, Kostamo K, Virkkula P, et al. Local and systemic proteolytic responses in chronic rhinosinusitis with nasal polyposis and asthma. Int Forum Allergy Rhinol 2015; 5: 294-302.

Vignola AM, Bonanno A, Profita M, et al. Effect of age and asthma duration upon elastase and $\alpha_{1}$-antitrypsin levels in adult asthmatics. Eur Respir J 2003; 22: 795-801.

McElvaney NG, Stoller JK, Buist AS, et al. Baseline characteristics of enrollees in the National Heart, Lung and Blood Institute Registry of alpha 1-antitrypsin deficiency. Alpha 1-Antitrypsin Deficiency Registry Study Group. Chest 1997; 111: 394-403.

Eden E, Mitchell D, Mehlman B, et al. Atopy, asthma, and emphysema in patients with severe alpha-1-antitrypysin deficiency. Am J Respir Crit Care Med 1997; 156: 68-74.

Prados M, Monteseirín FJ, Carranco MI, et al. Phenotypes of alpha-1-antitrypsin in intrinsic asthma and ASA-triad patients. Allergol Immunopathol (Madr) 1995; 23: 24-28. $1384-1391$. van Veen IH, ten Brinke A, van der Linden AC, et al. Deficient alpha-1-antitrypsin phenotypes and persistent airflow limitation in severe asthma. Respir Med 2006; 100: 1534-1539.

Gadek JE, Klein HG, Holland PV, et al. Replacement therapy of alpha 1-antitrypsin deficiency. Reversal of protease-antiprotease imbalance within the alveolar structures of PiZ subjects. J Clin Invest 1981; 68: 1158-1165.

Wencker $\mathrm{M}$, Banik $\mathrm{N}$, Buhl $\mathrm{R}$, et al. Long-term treatment of $\alpha_{1}$-antitrypsin deficiency-related pulmonary emphysema with human $\alpha_{1}$-antitrypsin. Wissenschaftliche Arbeitsgemeinschaft zur Therapie von Lungenerkrankungen (WATL)-alpha1-AT-study group. Eur Respir J 1998; 11: 428-433.

Seersholm N, Wencker M, Banik N, et al. Does $\alpha_{1}$-antitrypsin augmentation therapy slow the annual decline in FEV1 in patients with severe hereditary $\alpha_{1}$-antitrypsin deficiency? Wissenschaftliche Arbeitsgemeinschaft zur Therapie von Lungenerkrankungen (WATL) alpha1-AT study group. Eur Respir J 1997; 10: 2260-2263.

Dirksen A, Dijkman JH, Madsen F, et al. A randomized clinical trial of $\alpha_{1}$-antitrypsin augmentation therapy. Am J Respir Crit Care Med 1999; 160: 1468-1472.

Wencker M, Fuhrmann B, Banik N, et al. Longitudinal follow-up of patients with $\alpha_{1}$-protease inhibitor deficiency before and during therapy with IV $\alpha_{1}$-protease inhibitor. Chest 2001; 119: 737-744.

Sorrells S, Camprubi S, Griffin R, et al. SPARTA clinical trial design: exploring the efficacy and safety of two dose regimens of alpha1-proteinase inhibitor augmentation therapy in alpha1-antitrypsin deficiency. Respir Med 2015; 109: 490-499.

9 Campos MA, Kueppers F, Stocks JM, et al. Safety and pharmacokinetics of $120 \mathrm{mg} / \mathrm{kg}$ versus $60 \mathrm{mg} / \mathrm{kg}$ weekly intravenous infusions of alpha-1 proteinase inhibitor in alpha-1 antitrypsin deficiency: a multicenter, randomized, double-blind, crossover study (SPARK). COPD 2013; 10: 687-695.

Edgar RG, Patel M, Bayliss S, et al. Treatment of lung disease in alpha-1 antitrypsin deficiency: a systematic review. Int J Chron Obstruct Pulmon Dis 2017; 12: 1295-1308.

Sandhaus RA, Turino G, Stocks J, et al. alpha1-Antitrypsin augmentation therapy for $\mathrm{PI}^{\star} \mathrm{MZ}$ heterozygotes: a cautionary note. Chest 2008; 134: 831-834. 